\title{
Memória
}

\section{A brief history of Tourette syndrome}

In 1885, at the behest of his mentor Charcot, Gilles de la Tourette published a two-part article which identified a combination of multiple motor tics and "involuntary" vocalizations that over time increased in number and variety with the eventual appearance of eruptive cursing that he designated "coprolalia." ${ }^{1}$ He labeled this disorder maladie des tics convulsifs avec coprolalie, insisting that it was distinct from choreas and hysterias. Based on nine patients' case histories, Gilles de la Tourette concluded that although it signs and symptoms might wax and wane, the disease ultimately resisted all interventions. ${ }^{2}$ There was no hope of "a complete cure," wrote Gilles de la Tourette, for clinical experience demonstrated that "once a ticcer, always a ticcer.",3,1

As his first and prototypical example of tic disease Gilles de la Tourette cited case of the Marquise de Dampierre, a French noblewoman notorious for publicly shouting out, in the middle of conversations, inappropriate or obscene words, especially "shit and fucking pig." Dampierre's bizarre behavior originally had been reported in 1825 by Itard. ${ }^{4,5}$ According to Gilles de la Tourette convulsive tic disease had a "degenerative" hereditary etiology. ${ }^{1}$ Advocates of degeneration theory argued that diet and habits such as alcoholism and immoral behavior had a cumulative destructive effect on the nervous system that was inherited by succeeding generations. ${ }^{2,6}$

Because they had identified a set of signs and symptoms, a course of illness, and a predisposing cause, Gilles de la Tourette and Charcot insisted that they had described a disease. This construction of convulsive tic disease was challenged by their Parisian colleagues, who claimed that case histories of their patients revealed that multiple motor tics, coprolalia, and echolalia were found in both hysterics and choreics. ${ }^{7-9}$ As a result of these and other criticisms, Charcot and Gilles de la Tourette conceded that motor and vocal tics and coprolalia were also symptoms of hysteria, and, therefore, these symptoms and signs were not unique to Gilles de la Tourette's disease., 10-12 A diagnosis of convulsive tic disease could be made only when the tics and vocalizations persisted, resisting all interventions, and when a patient revealed a history of degeneration. Thus, Gilles de la Tourette's disease is not the same as what today is labeled Tourette syndrome.

Outside Charcot's circle, most physicians believed that multiple motor tics and coprolalia were a subset or variation of choreas. Although medical commentators throughout the nineteenth century observed clusters of symptomatic differences that might justify separating each form of chorea as a distinct disorder, they rejected the view that variations in sign presentation automatically indicated distinct etiologies. This view meshed with a widespread and long-held belief that most, if not all, choreas were connected with a prior attack of rheumatic fever. ${ }^{13,14}$ Since rheumatic disease manifested itself in varying ways in different hosts, differences in symptom presentations were not seen as overwhelming evidence of distinct disease entities. ${ }^{13,15-16}$

Rejected by critics within the Salpêtrière and ignored by those who believed convulsive tics were a subset of choreas, maladie des tics de Gilles de la Tourette was increasingly marginalized. The publication of Meige and Feindel's influential 1902 study, Les Tics et leur Traitement, furthered this process. ${ }^{17,18}$ According to Meige and Feindel, only a minority of ticcers fit Gilles de la Tourette's description. ${ }^{18}$ Most tics and involuntary vocalizations resulted from uncorrected infantile habits in a population with hereditary weakness.

Meige and Feindel's hereditary view proved compatible with eugenics, and it also segued into Freudian explanations of early childhood sexual repressive conflict. In 1921, the Hungarian psychoanalyst, Ferenczi and his followers argued that tics resulted from repressed masturbatory desires and that tics were "stereotyped equivalents of masturbation" and that eruptive cursing was a symbolic and linguistic substitute for masturbation. ${ }^{19}$

Meige and Feindel's book, supplemented by Ferenczi's views, influenced the diagnosis and treatment of tics well into the 1940s. But psychogenic claims continued to be challenged by evidence implicating physiological causes of tics. The worldwide epidemic of infectious encephalitis (1918-1926), in which tics were a common sequel, supplied persuasive evidence that the etiology of tics and coprolalia were post-infectious rather than psychological. ${ }^{20}$ Additional evidence in support of organic explanations came from advocates of focal infection theory who reported that surgical removal of infected organs, such as sinuses or tonsils, relieved a patient's tics. ${ }^{21}$

One solution to the contradictory claims of psychoanalysis and postinfectious theories was to separate patients for treatment based on examination of their case histories. Those who revealed a correlation between infection and subsequent tics could be treated biologically, while those without organic disease could be candidates for psychoanalysis. However, most patients' case histories were replete with evidence that could be marshaled to support whatever assumptions an examining physician brought to the clinical encounter. As a result, patients with similar medical histories and symptoms received different treatments depending on the philosophy and training of their particular physicians.

By the 1930s, some practitioners seemed so uncertain about the causes of tics and involuntary vocalizations that they concluded that each symptom had a separate and unrelated cause. $^{22,23}$ Alternatively, developmental psychologists, emphasizing that tics were a common feature of normal childhood, called into question the assumptions that tics were ipso facto evidence of mental or physical illness. Instead, they 
viewed convulsive tic symptoms as a form of normal early childhood behavior distorted by environmental pressures. ${ }^{24} \mathrm{By}$ the end of the 1930s, tic, as a separate category of disease, fell into decline because its symptoms were understood as one possible, but not exclusive, result of an underlying psychological conflict or a previous infection.

When Gilles de la Tourette's name began to reappear in medical literature in the 1940s, his explanations were shorn of their organic and hereditary baggage and portrayed as if his arguments had been exclusively psychogenic. ${ }^{25}$ American psychoanalysts, led by an influential group of central European emigrés, resurrected Gilles de la Tourette's name, attaching his typology to a variety of psychoanalytic categories of explanation. Under the guidance of Mahler, a generation of American psychiatrists learned that the symptoms described by Gilles de la Tourette were signs of a deeper psychosexual disturbance, albeit informed by organic factors. Mahler and her colleagues transformed Gilles de la Tourette's tic disease into a syndrome, in which the tic itself would be less the object of treatment than some putative, repressed set of childhood sexual conflicts.

Mahler's clinical case histories served as models for a generation of practitioners, even though she concluded that psychoanalysis was ineffective for amelioration of tics. ${ }^{26-27}$ Following Mahler, psychoanalysts in the next two decades repeated, as if it were a medical mantra, that tic disorders resisted psychoanalytic interventions because "the role of the tic" was "the last 'desperate defense against psychosis". ${ }^{28-30}$

Psychoanalytic assumptions were so pervasive that the discovery in the 1960s of the effectiveness of haloperidol as a tic suppressor did not challenge most psychiatrists' assumptions that psychosexual conflict was the underlying cause of motor and vocal tics. From 1963 to 1967, two University of Iowa teams reported success with haloperidol on a group of ticcing and coprolalic patients for whom all previous interventions had failed. ${ }^{31,32}$ Nevertheless, they concluded that "it should be obvious that the problem of Tourette's disease is not resolved by control of the tics through medication." ${ }^{32-34}$ By 1968, a consensus had developed among North American psychiatrists and neurologists that although haloperidol was an extremely effective agent for the management of motor tics and coprolalia, Mahler had been correct that the underlying enabling factors were psychodynamic. ${ }^{35,36}$

The widespread acceptance of psychoanalytic assumptions, combined with the power that the psychoanalytic community welded over medical journal editorial boards, made it extremely difficult for those few practitioners who were convinced that TS had an organic etiology to gain a professional platform in the 1970s. Ultimately, it took an alliance between a persistent psychiatrist/psychologist team and families of the afflicted to confront the psychoanalytic paradigm.

In 1968 Shapiro and Shapiro reported their successful treatment of a 24-year-old woman with an array of motor tics and vocalizations with haloperidol. They concluded that the etiology of these symptoms was organic and presented their findings as evidence of the therapeutic and intellectual paucity of psychoanalytic psychiatry. ${ }^{37,38}$ The Shapiros' article established the label "Gilles de la Tourette's syndrome" as the descriptor of a neurological disorder that by definition stood in opposition to psychoanalytic claims. Although they emphasized Gilles de la Tourette's 1885 description of symptoms, the Shapiros rejected his view that tics had a degenerative etiology. With an obvious reference to Mahler's patients, the Shapiros warned that psychoanalytic treatment of these symptoms "may result in iatrogenic psychopathology." ${ }^{37}$

The Shapiros' patient's case story appealed to parents unwilling to accept blame for their children's symptoms. By the early 1970 s similar stories began to appear in newspapers and magazines throughout North America about children with motor movements and eruptive vocalizations, shunted from pediatrician to psychiatrist, whose parents were told that the behaviors resulted from their parenting. After years of failed psychotherapeutic and behavioral modification treatments, each family learned that these odd behaviors were caused by a chemical imbalance or neurotransmission malfunction, which was most likely amenable to treatment with haloperidol. ${ }^{38}$

Dissemination of these stories in the media and in physician training films was the work of several families of Shapiros' patients who had organized the group to form the Tourette Syndrome Association (TSA). The TSA pursued a variety of strategies: they referred ticcing patients to the Shapiros and later to like-minded colleagues; publicized the disease in a variety of venues; and recruited influential psychiatrists and celebrities to their cause. They also persuaded researchers to investigate the organic factor of tics by providing generous sources of funding for research. These activists established a national network and support group. ${ }^{40-42}$

Today, TSA, Inc., has over 30,000 members with chapters in almost every part of the United States. It boasts a medical board of directors made up of respected research neurologists, psychiatrists, and pediatricians from premier North American medical schools in the United States and Canada, as well as prominent researchers from the National Institutes of Mental Health. ${ }^{43}$ Parallel organizations have been set up in Canada, Britain, and, recently, in Norway. The number of diagnoses in the United States and Canada now exceeds 200,000. Millions of dollars a year are expended for research on the organic causes and treatment of Tourette syndrome.

Increasing energy has focused on the search for a genetic component, but disputes over the TS phenotype continue to hinder attempts to locate a genetic substrate. Initial publications on the genetics of TS by Comings relied on a much wider definition of the phenotype (including alcoholism and conduct disorder) than most in the TSA or medical research community were willing to tolerate. ${ }^{44}$ Although they disagreed with Comings's phenotype, Pauls and Leckman ${ }^{45}$ and their colleagues at Yale have led the search for a genetic etiology of TS. However, after more than a decade of intensive investigations, initial hope for a simple Mendelian (dominant) genetic etiology has been dashed and replaced by the more difficult task of exploring the genome for polygenic factors. ${ }^{46}$ 
Simultaneously, though not necessarily in contradiction to genetic research, there has been a rediscovery and renewed interest in an infectious substrate, particularly the role of antibodies to Group A beta hemolytic streptococcus (GABHS) based on the Sydenham's model. ${ }^{47-49}$ This research has implicated GABHS as possibly providing the environmental trigger in genetically susceptible families for a variety of movement disorders including Tourette syndrome. ${ }^{13,50-52}$ If the neuronal antibody theory is sustained, there may be a variety of routes to development of TS symptoms; and rather than

\section{References}

1. Tourette GG. Étude sur une affection nerveuse caractérisée par de l'incoordination motrice accompagnée d'écholalie et de coprolalie (jumping, latah, and myriachit). Arch Neurol 1885;9:19-42,158-200.

2. Charcot J-M. Leçons du Mardi à la Salpêtrière Policliniques. Notes de Cours de MM Blin, Charcot et Colin [Hand-written and printed]. Paris: Bureaux du Progrès Médical; 1887-1888.

3. Tourette GG. La maladie des tics convulsifs. La Semaine Médicale 1899;19:153-6.

4. Itard JMG. Mémoire sur quelques fonctions involontaires des appareils de la locomotion, de la préhension et de la voix. Arch Gen Med $1825 ; 8: 385-407$.

5. Kushner HI. Medical fictions: the case of the cursing marquise and the (re)construction of Gilles de la Tourette's syndrome. Bull Hist Med 1995;69:224-54.

6. Dowbiggin IR. Inheriting Madness: Professionalization and Psychiatric Knowledge in Nineteenth-Century France. Berkeley: University of California Press; 1991 p. 1-10, 116-143.

7. Guinon G. Sur la maladie des tics convulsifs. Rev Med 1886;6:50-80.

8. Guinon G. Tics convulsifs et hystérie. Rev Med 1887;7:509-19.

9. Brissaud E. La chorée variable des dégénérés. Rev Neurol 1896;4:417-31.

10. Kushner HI. Freud and the diagnosis of Gilles de la Tourette's illness. Hist Psychiatry 1998;8:1-25.

11. Charcot J-M. Des tics et des tiqueurs. La Tribune Med 1888;19:571-3.

12. Catrou J. Étude sur la maladie des tics convulsifs (jumping--latah--myriachit) [Thèse pour le Doctorat]. Paris: Faculté de Médedice de Paris Henri Jouve; 1890.

13. Kushner HI, Kiessling LS. The controversy over the classification of Gilles de la Tourette's syndrome, 1800-1995. Perspect Biol Med 1996;39:409-35.

14. Cooke HP. The relation of chorea to rheumatism. Trans Texas State Med Assoc 1892;146-53.

15. Leredde E. Note sur un cas d'endocardite choréique d'origine microbienne probable. Rev Mensuelle Maladies de L'Enfance 1891:9:217-20.

16. Massalongo R. Chorée chez deux cardiques. Rev Neurol 1895;3:610-5.

17. Meige H, Feindel E. Les Tics et leur Traitement. Preface by Professor Brissaud. Paris: Masson; 1902.

18. Meige H, Feindel E. Tics and their Treatment, with a preface by Professor Brissaud. Wilson SAK, trans, ed. New York: William Wood and Co.;1907.

19. Ferenczi S. Psycho-analytical observations on tic. Int J Psychoanal 1921;2:1-30.

20. Straus E. Über die organische natur der tics und der koprolalie. Zentralblatt für die gesamte Neurol Psychiatr 1927;47:698-9.

21. Selling L. The role of infection in the etiology of tics. Arch Neurol Psychiatry 1929;22:1163-71.

22. Hassin GB, Stenn A, Burstein JJ. Stereotyped acts or attitude tics? A case with a peculiar anomaly of gait. J Nerv Ment Dis $1930 ; 71: 27-32$. looking at one disease, there may be several different routes to similar sign/symptom clusters. ${ }^{* 53-55}$ What seems evident from an historical perspective is we have no reason to conclude that the final formulation of the elements that constitute tics and related disorders, let alone their etiological mechanisms, have been identified.

Howard I. Kushner

San Diego State University, San Diego, USA e University of California, San Diego, USA

23. Saussure R. Discussion sur l'étiologie d'un tic survenu quinze mois après une encéphalite léthargique atypique. Schwizer Archiv für Neurol Psychiatr 1923;12:294-317.

24. Blatz WE, Ringland MC. A Study of Tics in Pre-School Children. Toronto: University of Toronto Press; 1935.

25. DeWulf A, van Bogaert L. Études anatomo-cliniques de syndrômes hypercinétiques complexes. Monatsschrift für Psychiatr Neurol 1941;104:53-61.

26. Mahler MS, Rangell L. A psychosomatic study of maladie des tics (Gilles de la Tourette's syndrome). Psychiatr Q 1943;17:579-603.

27. Mahler MS, Luke JA, Daltroff W. Clinical and follow up study of the tic syndrome in children. Amer J Orthopsychiatry 1945;15;631-47.

28. Michael RP. Treatment of a case of compulsive swearing. Br Med J 1957; 1:1506-8, 42:1507.

29. Heuscher JE. Intermediate state of consciousness in patients with generalized tics. J Nerv Ment Dis 1953;117:29-38.

30. Eisenberg L, Ascher E, Kanner L. A clinical study of Gilles de la Tourette's disease (maladie des tics) in children. Am J Psychiatry 1959; 115:715-23.

31. Challas G, Brauer W. Tourette's disease: relief of symptoms with r.1625. Am J Psychiatry 1963;120:283-4.

32. Chapel JL, Brown N, Jenkins RL. Tourette's disease: symptomatic relief with haloperidol. Am J Psychiatry 1964;121:608-10.

33. Challas G, Chapel J, Jenkins RL. Tourette's disease: control of symptoms and its clinical course. Int J Neuropsychiatry 1967;3:95-109.

34. Chapel JL. Gilles de la Tourette's disease, the past and the present Can Psychiatric Assoc J 1966;1:324-9.

35. Corbin KB, Field JR, Goldstein NP. Klass DW. Further observations on Tourette's syndrome. Proc Australian Assoc Neurol 1968;5:447-53.

36. Fernando SJM. Gilles de la Tourette's syndrome. Br J Psychiat 1967;113:607-17.

37. Shapiro AK, Shapiro E. Treatment of Gilles de la Tourette's syndrome with haloperidol. Br J Psychiat 1968;114:345-50.

38. Shapiro AK, Shapiro ES, Bruun RD. Sweet RD. Gilles de la Tourette Syndrome. New York: Raven Press; 1978 p. 1-9.

39. Kushner HI. A Cursing Brain?: the histories of Tourette Syndrome. Cambridge, Mass: Harvard University Press; 1999.

40. Shapiro ES, Shapiro AK, Sweet RD, Bruun RD. The diagnosis, etiology and treatment of Gilles de la Tourette's syndrome. Mental Health in Children. Vol I. Genetics, family and community studies. ed. Sankar DVS. Westbury, NY: PJD Publication; 1975. p. 167-73.

41. Wertheim J. A 10th anniversary message: who we are, how we help. TSA Newsletter 1982;9(2):1-2.

42. Shapiro AK. Remarks at the tenth anniversary membership meeting of the Tourette Syndrome Association. 22 May 1982. Mt. Sinai Hospital, New York City. [Reprinted] TSA Newsletter 1982;9(3):1-2.

43. Levi-Pearl S. The Tourette Syndrome Association, inc. Handbook of Tourette's Syndrome and Related Tic Disorders. Kurlan R, ed. New York: Marcel Dekker; 1993. p. 515-21. 
44. Comings DE. Search for the Tourette Syndrome and Human Behavior Genes. Duarte, Calif: Hope Press;1996.

45. Pauls DL, Leckman JF. The inheritance of Gilles de la Tourette's syndrome and associated behaviors: evidence for autosomal dominant transmission. N Engl J Med 1986;315:993-7.

46. Barr CL, Wigg KG, Pakstis AJ, Kurlan R, Pauls D, Kidd KK, et al. Genome scan for linkage to Gilles de la Tourette syndrome. Am J Med Genet 1999:20;88437-45.

47. Taranta A, Stollerman GH. Relationship of Sydenham's chorea to infection with Group A streptococci. Am J Med 1956;20:170-5.

48. Husby G, Van de Rijn I, Zabriskie JB, et al. Antibodies reacting with cytoplasm of subthalamic and caudate nuclei neurons in chorea and rheumatic fever. J Exp Med 1976;1094-110.

49. Swedo SE. Sydemhan's Chorea: A model for childhood autoimmune neuropsychiatric disorders. JAMA 1994;272:1788-91.

50. Kiessling LS, Marcotte AC, Benson M, Kuhn C, Wrenn D. Relationship between GABHS and childhood movement disorders [Abstract]. Pediatr Res 1993;33(part 2):12a.
51. Swedo SE, Leonard HL, Kiessling LS. Speculations on antineuronal antibody-mediated neuropsychiatric disorders of childhood. Pediatrics 1994;93:323-6.

52. Swedo SE, Leonard HL, Mittleman BB, Allen AJ, et al. Identification of children with pediatric autoimmune neuropsychiatric disorders associated with streptococcal infections by a marker associate with rheumatic fever. Am J Psychiatry 1997;154:110-2.

53. Allen AJ, Leonard HL, Swedo SE. Case study: a new infection-triggered, autoimmune subtype of pediatric ocd and Tourette's syndrome. J Am Acad Child Adolesc Psychiatry 1995;34:307-11.

54. Leckman JF, Peterson BS, Anderson GM, Arnsten AMFT, Pauls DL, Cohen DJ. Pathogenesis of Tourette's syndrome. J Child Psychol Psychiatry 1997;38:119-42.

55. Kurlan R. Future direction of research in Tourette syndrome. Neurol Clin 1997;15:451-6. 